\title{
Congenital Glaucoma and Associated Anomalies
}

\author{
Pio Impagliatelli* \\ Ophthalmology Department at University Hospital "UMBAL Aleksandrovska" \\ Bulgaria, Balkans \\ *Corresponding Author: Pio Impagliatelli, Ophthalmology Department at \\ University Hospital “UMBAL Aleksandrovska” Bulgaria, Balkans.
}

DOI: $10.31080 /$ ASOP.2020.03.0094

Infantile or malformative glaucoma can occur in a high percentage of cases associated with ocular and systemic abnormalities. In some cases, atypical forms of associated glaucoma are not diagnosed early either because the characteristic signs of childhood glaucoma are not always present or because many of these associations are little known to the ophthalmologist. This occurrence is particularly evident for those forms of glaucoma that late complicate some systemic disorders or plurimalformative syndromes. The recognition of these forms is important because in many cases the presence of some associations profoundly changes, generally in a pejorative sense the prognosis of the disease, forcing different choices of treatment and also influencing the possibility of functional recovery. The best knowledge of the associated forms of infantile glaucoma on a malformative basis assumes great interest on a practical level also for the purposes of genetic counseling. Hereditary transmission (20 - 25\% of cases) in simple malformative glaucoma is typically autosomal recessive, only $3 \%$ is transmitted with the characters of dominance. As regards the forms of associated glaucoma, the modalities of transmission vary greatly from case to case and are related to the underlying disease. We consider congenital or infantile glaucoma associated with ocular and systemic abnormalities that are often present simultaneously.

Malformative glaucoma associated with ocular anomalies

Among ocular anomalies we consider dysgenesis-cleavage anomalies, corneal anomalies, iris anomalies, lens anomalies, pure and associated microphthalmos.

Dysgenesis - cleavage anomalies

Axenfeld syndrome characterized by the presence of embryotoxon and iris processes adhering to the Schwalbe line. Glaucoma is present in over $50 \%$ of cases. Rieger's syndrome in which, in addition to embryotoxon, there is an iridescent hypoplasia with a flowered appearance, pseudopolycoria, pupillary ectopia, angle anomalies and multiple systemic defects. Peters syndrome in which, in addition to the signs present in the previous ones, there is a posterior defect of the cornea with consequent corneal leukoma adhering to the lens and iris. Systemic associations are very serious and include: mental retardation, cerebellar hypoplasia, cleft palate, dental anomalies, partial absence of facial bones and hypospadias.

\section{Associated corneal anomalies}

In the megalocornea and in the keratoglobe, even when glaucoma is not present at birth, the child must be considered at high risk and therefore subjected to periodic checks until adulthood.

\section{Iris anomalies}

Aniridia is the most frequently associated iris defect in glaucoma, it presents a multifaceted clinical expressiveness with a range that goes from the complete form to the pictures of aplasia or hypoplasia, coloboma, polycoria. Glaucoma in aniridia is present in over $50 \%$ of cases, although it is not always congenital, but can occur after early childhood. Its pathogenesis seems to be attributable both to congenital structural anomalies of the corner and to the progressive apposition of iris tissue in the trabecular meshwork.

\section{Lens anomalies}

In some cases glaucoma can be considered of a secondary type as in the ectopias of the lens (homocystinuria, Marfan, Marchesani); however congenital anomalies of the corner can also be detected in these cases. More typical are the associations with congenital aphakia, lenticone (present in Alport's syndrome) and lentiglobe. 
Congenital glaucoma associated with systemic disorders

- Chromosomal abnormalities: Many chromosomal aberrations are associated with malformative glaucoma, among them: Down syndrome, whose glaucoma is often primary; Patau syndrome (trisomy 13-15), in these cases glaucoma is more secondary; Wolff syndrome (4p-) where glaucoma has the typical malformative aspect.

- Congenital errors of metabolism: Lowe's syndrome (oculocerebrorenal) a serious recessive inherited X-linked syndrome whose gene is located on the long arm of the $\mathrm{X}$ chromosome (Xq24-q26); in 90\% of cases there is a cataract while glaucoma has a frequency of $75 \%$ and is not always congenital.

- Defined multisystem syndromes: In Ehlers-Danlos syndrome (type VI) and in the fragile cornea syndrome variant there is a deficit of collagen stability due to a defect in the fibroblasts of the proto-collagen enzyme lysyl hydroxylase. There are many ocular defects, including glaucoma which can be both malformative and secondary to the lens dislocation. In Rubinstein-Taybi syndrome: dwarfism, dysmorphism, large thumb and big toe, mental retardation, malformative glaucoma. In Hallerman-Streiff-Francois syndrome (bird face dyscephaly) there is dwarfism, micrognathy and congenital cataract; glaucoma is associated with microphthalmos and rainbow hypoplasia.

- Facomatosis: Glaucoma can be observed in von Recklinghausen type 1 neurofibromatosis. Various hypotheses have been formulated on its pathogenesis: 1) infiltration of the corner by neurofibromatous tissue 2) structural anomalies of the angle 3) progressive closure of the angle by choroidal neurofibromas 4) obstruction of the Schlemm canal 5) neurogenic hypersecretion.

\section{Assets from publication with us}

- Prompt Acknowledgement after receiving the article

- Thorough Double blinded peer review

- Rapid Publication

- Issue of Publication Certificate

- High visibility of your Published work

Website: www.actascientific.com/

Submit Article: www.actascientific.com/submission.php

Email us: editor@actascientific.com

Contact us: +919182824667

Citation: Pio Impagliatelli. “Congenital Glaucoma and Associated Anomalies”. Acta Scientific Ophthalmology 3.3 (2020): 08-09. 